\title{
CLUSTERING MINAT DAN BAKAT MAHASISWA TEKNIK INFORMATIKA BERDASARKAN BIDANG KEAHLIAN, MATA KULIAH FAVORIT, DAN INDEKS PRESTASI MAHASISWA
}

\author{
Masruroh; Ayu Ismi Hanifah \\ masruroh@unisla.ac.id; ayuismi@unisla.ac.id \\ Teknik, Informatika, Fakutas Teknik, Universitas Islam Lamongan
}

\begin{abstract}
ABSTRAK
Minat dapat diartikan ketertarikan seseorang terhadap sesuatu, sedangkan bakat merupakan potensi bawaan yang membuat seseorang menguasai sesuatu dengan mudah. Gabungan keduanya merupakan modal yang besar bagi seseorang untuk sukses di bidangnya. Penelitian ini bertujuan untuk mendeskripsikan hasil clustering minat dan bakat mahasiswa berdasarkan bidang keahlian, mata kuliah favorit, dan Indeks prestasi sekaligus respon yang didapatkan dari mahasiswa. Data didapatkan dari 94 mahasiswa teknik informatika Universitas Islam Lamongan sebagai sampel. Data bidang keahlian, mata kuliah favorit dan respon mahasiswa didapatkan dari kuesioner, sedangkan data indeks prestasi mahasiswa (IPK) didapatkan dari dokumen bagian kemahasiswaan sistem informasi akademik Universitas Islam Lamongan. Data yang didapatkan kemudian dianalisis menggunakan bantuan Matlab menggunakan metode Fuzzy C Means untuk mementukan cluster minat dan bakat. Hasil clustering menunjukkan 50\% mahasiswa memiliki minat dan bakat di bidang pemrograman, $40 \%$ di bidang jaringan, dan $10 \%$ di bidang desain. Hasil respon mahasiswa menunjukkan $48 \%$ mahasiswa menyatakan cukup puas terhadap hasil clustering, 53\% mahasiswa menyatakan hasil clustering ini bermanfaat, dan 48\% mahasiswa menyatakan hasil clustering ini cukup membantu mereka dalam merencanakan pemilihan karir di masa depan. Secara umum dapat dikatakan bahwa hasil clustering minat dan bakat ini mendapatkan respon yang cukup baik dari mahasiswa Teknik Informatika.
\end{abstract}

Kata Kunci: Clustering, Minat, Bakat, Bidang Keahlian, Mata Kuliah Favorit, Indeks Prestasi

\section{PENDAHULUAN}

\section{Minat dan Bakat}

Minat menurut Kamus Besar Bahasa Indonesia (2017) didefinisikan sebagai kecenderungan hati yang tinggi, gairah, keinginan. Sedangkan menurut Nurhasanah dan Sobandi (2016) minat dapat diartikan sebagai suatu rasa lebih suka, rasa ketertarikan, perhatian, fokus, ketekunan, usaha, pengetahuan, keterampilan, motivasi, pengatur perilaku, dan hasil interaksi seseorang dengan konten atau kegiatan tertentu. Suharyat (2009) menambahkan bahwa secara umum, minat dapat diartikan sebagai usaha dan kemauan untuk mempelajari dan mencari sesuatu, minat juga dapat diartikan sebagai dorongan pribadi untuk mencapai tujuan tertentu.
Minat dapat diartikan ketertarikan seseorang terhadap sesuatu, sedangkan bakat merupakan potensi bawaan yang membuat seseorang menguasai sesuatu dengan mudah. Gabungan keduanya merupakan modal yang besar bagi seseorang untuk sukses di bidangnya.

Minat berhubungan erat dengan hasil belajar. Hal ini seperti yang dikemukakan oleh Nurhasanah dan Sobandi (2016) bahwa minat memiliki pengaruh yang signifikan terhadap hasil belajar. Hidi, Berndoff, dan Ainley (dalam Nurhasanah dan Sobandi, 2016) menambahkan minat juga memberikan pengaruh positif terhadap pembelajaran akademik, domain pengetahuan, dan bidang studi tertentu bagi individu.

Pengenalan minat dan bakat menjadi hal yang penting untuk dilakukan. Dengan memahami potensi yang berupa minat dan 
bakat yang dimiliki akan mendorong mahasiswa untuk dapat mengembangkan kemampuan menjadi lebih baik dengan mempelajari dan menekuni bidang keahlian dan mata kuliah tertentu yang sesuai dengan minat dan bakat mahasiswa (Yudihartanti dan Hidayatullah, 2014). Istiqamah (dalam Asmara dan Haryanto, 2015) menambahkan bahwa sangat penting bagi pengelola pendidikan dan institusi pendidikan serta masyarakat pada umumnya untuk mengetahui sejak dini potensi yang dimiliki siswanya, sehingga kelak siswa memiliki perencanaan karir yang berkualitas dan berdedikasi tinggi.

Pada kenyataannya sebagian besar orang belum mengetahui minat dan bakatnya masing-masing, padahal kesadaran akan potensi yang dimiliki baik berupa minat ataupun bakat sangat penting untuk menunjang kesuksesan karir seseorang dimasa depan. Kesadaran akan potensi diri ini bisa dimulai sejak masa pendidikan baik di sekolah ataupun di kampus. Secara psikologis siswa berada pada fase pematangan diri dan kedewasaan yang salah satunya dapat ditandai dengan mulai adanya kesadaran untuk memilih profesi atau pekerjaan di masa mendatang yang sesuai dengan minat dan bakatnya (Rufaidah, 2015).

Salah satu solusi yang dapat ditawarkan untuk memudahkan mahasiswa mengenali minat dan bakatnya adalah dengan mengelompokkan minat dan bakat mahasiswa berdasarkan beberapa faktor. Faktor-faktor tersebut antara lain, bidang keahlian, mata kuliah favorit, dan indeks prestasi (IPK).

Penelitian ini bertujuan untuk mendeskripsikan hasil clustering minat dan bakat mahasiswa berdasarkan bidang keahlian, mata kuliah favorit, dan indeks prestasi. Penelitian ini juga bertujuan untuk mendeskripsikan respon mahasiswa terhadap hasil clustering tersebut. Dengan adanya penelitian ini diharapkan dapat membantu mahasiswa dalam menentukan minat dan bakatnya sebagai bahan pertimbangan dalam menentukan karir di masa depan.

\section{Clustering dengan algoritma Fuzzy C Means}

Clustering data merupakan suatu proses pengelompokan data ke dalam cluster berdasarkan parameter tertentu sehingga obyek-obyek yang ada dalam suatu cluster memiliki kemiripan sifat satu sama lain namun tidak memiliki kemiripan dengan obyek lain dalam cluster yang berbeda (Asfi, dalam Simbolon, Kusumastuti, dan Irawan, 2013). Hermawati (dalam Akbar, 2015) mendefinisikan clustering data sebagai proses mempartisi data set menjadi beberapa sub set atau kelompok sedemikian rupa sehingga elemen-elemen dari suatu kelompok tertentu memiliki set properti yang dishare bersama. Dengan demikian, dapat clustering data dapat diartikan sebagai suatu proses pengelompokan data sehingga objek-objek dalam suatu kelompok akan memiliki kemiripan sifat satu sama lain namun berbeda sifat dengan anggota kelompok lain.

Clustering data merupakan salah satu teknik yang digunakan untuk mengetahui pola kecenderungan suatu data (Simbolon, Kusumastuti, dan Irawan, 2013). salah satu teknik yang digunakan untuk clustering data adalah menggunakan algoritma Fuzzy $C$ Means (FCM). Fuzzy C Means adalah teknik clustering data dimana keberadaan tiap titik data dalam cluster tersebut ditentukan oleh derajat keanggotaannya (Kusumadewi dan Purnomo, 2010). FCM memiliki kelebihan dapat melakukan clustering lebih dari satu variabel secara sekaligus (Simbolon, Kusumastuti, dan Irawan , 2013).

Menurut Afifah, Rini, dan Lubab (2016) FCM adalah metode yang banyak digunakan untuk menyelesaikan permasalahan yang berhubungan dengan cluster atau klasifikasi. Penggunaan FCM untuk clustering data sebelumnya telah 
dilakukan oleh Yudihartanti dan Hidayatullah (2014) dalam penelitiannya untuk menentukan minat topik tugas akhir mahasiswa dengan hasil penggunaan FCM dapat membantu mahasiswa dalam menentukan topik tugas akhir yang bisa dipilih. Hasil penelitian Akbar (2015) tentang clustering data nilai siswa SMA untuk menentukan jurusan juga menunjukkan bahwa penggunaan FCM untuk clustering data dapat membantu dan meningkatkan ketepatan pemilihan jurusan sebesar $72 \%$.

Konsep dasar FCM menurut Gelley (dalam Luthfi, 2007) adalah menentukan pusat cluster yang akan menandai lokasi rata-rata untuk tiap cluster. Pada kondisi awal pusat cluster ini masih belum akurat, sehingga diperlukan perbaikan pusat cluster secara berulang (Luthfi, 2007 dan Afifah, Rini, dan Lubab, 2016).

\section{METODE PENELITIAN}

Penelitian ini bertujuan untuk mendeskripsikan hasil clustering minat dan bakat mahasiswa berdasarkan bidang keahlian, mata kuliah favorit, dan indeks prestasi. Penelitian ini juga bertujuan untuk mendeskripsikan respon mahasiswa terhadap hasil clustering tersebut.

Data didapatkan dari 94 mahasiswa teknik informatika Universitas Islam Lamongan sebagai sampel. Data bidang keahlian, mata kuliah favorit, dan respon mahasiswa didapatkan dari kuesioner. Bidang keahlian yang dimaksud meliputi, database, pemrograman, jaringan, dan desain. Mata kuliah yang dimaksud adalah mata kuliah yang berhubungan dengan semua bidang keahlian yang telah ditempuh selama 6 semester. Sedangkan data indeks prestasi mahasiswa didapatkan dari dokumen bagian kemahasiswaan sistem informasi akademik Universitas Islam Lamongan. Indeks prestasi yang didapatkan merupakan Indeks Prestasi Kumulatif (IPK) mahasiswa angkatan 2015 semester
6 yang dijadikan sampel. Data bidang keahlian, mata kuliah favorit, dan indeks prestasi mahasiswa dikumpulkan sebagai bahan untuk menentukan clustering minat dan bakat mahasiswa, sedangkan data respon siswa dikumpulkan setelah hasil clustering selesai dianalisis dan dibagikan kepada mahasiswa. Analisis respon mahasiswa dilakukan dengan mempresentasekan tiap respon mahasiswa.

Proses clustering dalam penelitian ini dilakukan menggunakan bantuan Matlab dengan langkah-langkah sebagai berikut:

1) Input data yang akan dicluster dalam format Excel.

2) Data dari Excel kemudian dibaca di Matlab untuk dicari pusat datanya (centroid) menggunakan FCM

3) Hasil pusat data (centroid) yang didapatkan kemudian digunakan untuk menentukan clustering menggunakan euclidian distance. Hasil cluster yang didapatkan berupa cluster pemrograman, jaringan, dan desain.

\section{PEMBAHASAN \\ Hasil}

Hasil analisis clustering dengan Fuzzy $C$ Means menghasilkan centroid data yang dapat dilihat pada Tabel 1.

Tabel 1. Centroid data tiap custer

\begin{tabular}{cccc}
\hline Cluster & \multicolumn{3}{c}{ Centroid } \\
\hline Desain & 3.7782 & 1.7024 & 3.2521 \\
Pemrograman & 1.6014 & 1.6806 & 3.4201 \\
Jaringan & 3.3720 & 3.2906 & 3.1525
\end{tabular}

Hasil clustering minat dan bakat mahasiswa Teknik Informatika berdasarkan bidang keahlian, mata kuliah favorit, dan IPK dapat dilihat pada Gambar 1. 
Hasil clustering minat dan bakat mahasiswa

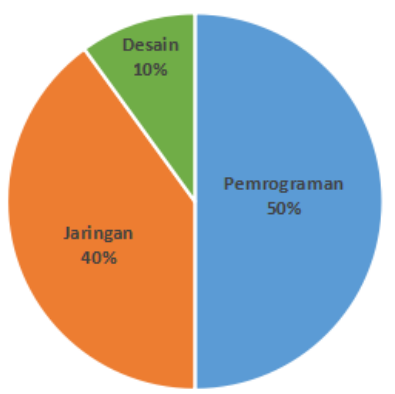

Gambar 1. Hasil clustering minat dan bakat mahasiswa Teknik Informatika

Berdasarkan Gambar 1 dapat dilihat bahwa $50 \%$ mahasiswa Teknik Informatika memiliki minat dan bakat di bidang pemrograman, $40 \%$ di bidang jaringan, dan $10 \%$ di bidang desain.

Respon mahasiswa terhadap hasil clustering minat dan bakat dapat dilihat pada Gambar 2.

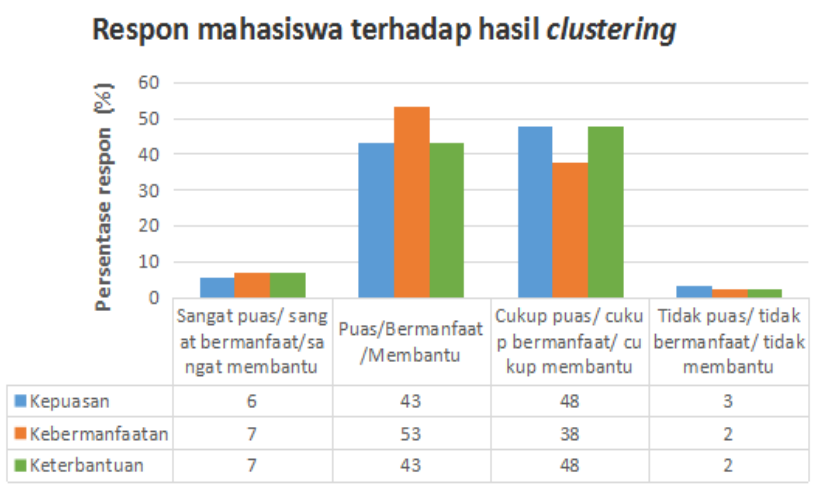

Gambar 2. Respon mahasiswa terhadap hasil clustering minat dan bakat

Gambar 2 menunjukkan bahwa $43 \%$ mahasiswa menyatakan puas dan $48 \%$ lainnya menyatakan cukup puas dengan hasil clustering minat dan bakat yang mereka peroleh. Sebanyak 53\% mahasiswa menyatakan hasil clustering bermanfaat bagi mereka dan 38\% mahasiswa lainnya menyatakan hasil clustering cukup bermanfaat bagi mereka. Sebanyak $43 \%$ mahasiswa menyatakan hasil clustering minat dan bakat membantu mereka dan 48\% lainnya menyatakan hasil clustering minat dan bakat membantu mereka dalam merencanakan karir di masa depan.
Hasil penilaian skor respon mahasiswa dapat dilihat pada Tabel 2 berikut.

Tabel 2. Skor respon mahasiswa

\begin{tabular}{|c|c|c|c|c|c|}
\hline \multirow[b]{2}{*}{ Kriteria } & \multicolumn{4}{|c|}{ Skor respon } & \multirow[b]{2}{*}{ Total } \\
\hline & $\begin{array}{l}\text { Sangat } \\
\text { baik(4) }\end{array}$ & $\begin{array}{c}\text { Baik } \\
\text { (3) }\end{array}$ & $\begin{array}{c}\text { Cukup } \\
\text { Baik (2) }\end{array}$ & $\begin{array}{c}\text { Tidak } \\
\text { baik } \\
(1)\end{array}$ & \\
\hline Kepuasan & 5 & 38 & 42 & 3 & 88 \\
\hline Kebermanfaatan & 6 & 47 & 33 & 2 & 88 \\
\hline Keterbantuan & 6 & 38 & 42 & 2 & 88 \\
\hline Jumlah & 17 & 123 & 117 & 7 & 264 \\
\hline Skor respon & 68 & 369 & 234 & 7 & 678 \\
\hline
\end{tabular}

Berdasarkan Tabel 2 di atas, rata-rata respon mahasiswa terhadap hasil clustering sebesar 3 atau secara umum dapat dikatakan bahwa hasil clustering minat dan bakat ini mendapatkan respon yang cukup baik dari mahsiswa Teknik Informatika.

\section{Diskusi}

Berdasarkan hasil clustering minat dan bakat mahasiswa Teknik Informatika dapat dipetakan bahwa 50\% mahasiswa Teknik Informatika memiliki minat dan bakat di bidang pemrograman, $40 \%$ di bidang jaringan, dan $10 \%$ di bidang desain. Hasil clustering mendapatkan ratarata skor respon sebesar 3 atau secara umum dapat dikatakan bahwa hasil clustering minat dan bakat ini mendapatkan respon yang cukup baik dari mahsiswa Teknik Informatika.

Hasil respon yang diperoleh cukup baik, mengingat kecocokan hasil clustering minat dan bakat mahasiswa yang belum maksimal, yakni hanya sebesar $50 \%$. Hal ini juga yang dimungkinkan membuat 3\% mahasiswa merasa tidak puas terhadap hasil clustering, 2\% mahasiswa menyatakan hasil clustering tidak bermanfaat, dan $2 \%$ mahasiswa menyatakan hasil clustering 
tidak membantu mereka dalam merencanakan karir di masa depan. Namun terlepas dari itu semua, secara umum hasil clustering ini dapat memetakan minat dan bakat mahasiswa Teknik Informatika

\section{KESIMPULAN}

\section{Simpulan}

Hasil clustering minat dan bakat mahasiswa Teknik Informatika berdasarkan bidang keahlian, mata kuliah favorit, dan IPK menunjukkan 50\% mahasiswa memiliki minat dan bakat di bidang pemrograman, $40 \%$ di bidang jaringan, dan $10 \%$ di bidang desain. Secara umum dapat dikatakan bahwa hasil clustering minat dan bakat ini mendapatkan respon yang cukup baik dari mahsiswa Teknik Informatika.

\section{Saran}

Hasil penelitian ini dapat digunakan oleh mahasiswa yang bersangkutan sebagai bahan pertimbangan ketika akan memutuskan karir apa yang akan ditekuni setelah lulus kuliah di prodi Teknik Informatika Universitas Islam Lamongan. Untuk penelitian selanjutnya bisa dilakukan penambahan variabel penentu minat dan bakat yang lainnya agar hasil yang didapatkan lebih akurat.

\section{UCAPAN TERIMAKASIH}

1. Terimakasih kepada

DRPM

Ristekdikti yang telah mendanai penelitian ini

2. Terimakasih kepada staf Sistem Informasi Akademik Universitas Islam Lamongan atas kerjasamanya dalam proses pengambilan data.

3. Terimakasih kepada mahasiswa Prodi Teknik Informatika Unisla angkatan 2015 atas kerjasamanya dalam proses pengambilan data.

4. Terimakasih kepada semua pihak yang telah membantu pelaksanaan penelitian ini. berdasarkan bidang keahlian, mata kuliah favorit, dan IPK dengan respon yang cukup baik dari mahasiswa.

\section{DAFTAR PUSTAKA}

Afifah, N., D., C., Rini, dan A. Lubab. 2016. Pengklasteran Lahan Sawah di Indonesia Sebagai Evaluasi Ketersediaan Produksi Pangan Menggunakan Fuzzy C Meanss. Jurnal Matematika Mantik, 2(1), 40-45.

Akbar, Fajar. 2015. Clustering Data Nilai Siswa SMA untuk Penentuan Jurusan Menggunakan Algoritma Fuzzy C Meanss. Jurnal Techno Nusa Mandiri. 12(1), 56-63.

Asmara, A. dan Haryanto. 2015. Pengembangan Tes Minat dan Bakat dengan Metode Jaringan Syaraf Tiruan untuk Memprediksi Potensi Siswa Bidang Robotika. Jurnal Pendidikan Vokasi. 5(3), 273286.

Kamus Besar Bahasa Indonesia (KBBI). 2018. Pengertian Minat. (Online) (https://kbbi.kemdikbud.go.id/en tri/minat) diakses 17 Oktober 2018.

Kusumadewi, S. dan H., Purnomo. 2010. Aplikasi Logika Fuzzy untuk Pendukung Keputusan. Yogyakarta: Graha Ilmu.

Luthfi, E., T. 2007. Fuzzy C Meanss untuk Clustering Data (Studi Kasus: Data Performance Mengajar Dosen). Prosiding Seminar Nasional Teknologi. Diadakan di Yogyakarta 24 November 2007. 
Reforma: Jurnal Pendidikan dan Pembelajaran

Vol. 7 No. 2 (2018)

p-ISSN: 2503-1228; e-ISSN: 2621-4172

Nurhasanah, S. dan Sobandi, A., 2016.

Menggunakan Algoritma Fuzzy Minat Belajar Sebagai Determinan Hasil Belajar Siswa. Jurnal pendidikan manajemen perkantoran, 1(1), 135-142.

Rufaidah, A.. 2015. Pengaruh Intelegensi dan Minat Siswa terhadap Putusan Pemilihan Jurusan. Faktor Jurnal Ilmiah Kependidikan, 2(2), 139-146.

Simbolon, C., L., N. Kusumastuti, dan B. Irawan. 2013. Clustering Lulusan Mahasiswa Matematika FMIPA UNTAN Pontianak C Meanss. Bimaster, 2(1), 2126.

Sudjana. 2005. Metoda Statistika, Bandung: Tarsito.

Suharyat, Y. 2009. Hubungan antara sikap, minat dan perilaku manusia. Jurnal Region, 1(3), 1-19.

Yudihartanti, Y., dan S. Hidayatullah. 2014. Pemilihan Minat Tugas Akhir Menggunakan Metode Fuzzy C Meanss. Justisi, 3(2), 527-534. 